Journal of Computer Networks, Architecture and

High Performance Computing

Volume 3, Number 2, April 2021

https://doi.org/10.47709/cnahpc.v3i2.981

Submitted : 15 June 2021

Accepted : 20 June 2021

Published : 19 July 2021

\title{
Lecturer Attendance System using Face Recognition Application an Android- Based
}

\author{
Feri Susanto $^{1)}$, Fauziah $^{2 *}$, Andrianingsih ${ }^{3)}$ \\ 1)2)3) Universitas Nasional, Indonesia. \\ ${ }^{1)}$ fersus1820@yahoo.com, ${ }^{2)}$ fauziah@civitas.unas.ac.id, ${ }^{3)}$ andrianingsih@civitas.unas.ac.id
}

\begin{abstract}
In the field of industries, businesses, and offices the use of security systems and administrative management through data input using a face recognition system is being developed. Following the era of technological advances, communication and information systems are widely used in various administrative operational activities and company security systems because it is assessed by using a system that is based on facial recognition security levels and more secure data accuracy, the use of such systems is considered to have its characteristics so it is very difficult for other parties to be able to engineer and manipulate data produced as a tool to support the company's decision. Related to this, causing the author is to try to research the detection of facial recognition that is present in the application system through an Android device, then face recognition detection will be connected. and saved to the database that will be used as data about the presence of teaching lecturers. Using the local binary pattern histogram algorithm method to measure the face recognition system that can be applied as a technique in the attendance system of lecturers to be more effective and efficient. Based on testing by analyzing the false rate error rate and the false refusal rate can be seen that the average level of local binary pattern histogram accuracy reaches $95.71 \%$ better than through the Eigenface method which is equal to $76.28 \%$.
\end{abstract}

Keywords: android, application system, attendance, face recognition, local binary pattern histogram.

\section{INTRODUCTION}

Utilization of technological advances, communication, and operational information systems, and administration of companies in the fields of industry, businesses, and offices continue to be encouraged to be able to adjust the development of the times that are happening, the aim is that the company can compete with other companies so that it can improve abilities and performance activities in the aim of creating maximum profits(Rosita \& Wibowo, 2021).

In administrative management to support the decision of a company, the development of science and technology through biological identification systems such as fingers, faces, retina, sounds, and others as input tools are widely used and developed(Gilang Aditya Rama, Fauziah, 2020). One reason why biological identification has been developed is the method has excellent accuracy and a very high level of security(Satria Putra, Iskandar Fitri, 2021). The background of this study was aimed at designing an effective and efficient teaching lecturer attendance system by using the face recognition method using the Local Binary Pattern Histogram (LBPH) algorithm method.

So with the background, the author conducted this research, in the preparation of the author limit the problems such as: How to design a system of database applications made to help solve problems, how to manage the presence of lecturers through the Face Recognition application, and how the teaching attendance system teaches This Android-based was built through facial recognition with the Local Binary Pattern Histogram algorithm (LBPH).

The purpose of this study is to produce a teaching lecturer attendance system with the Face Recognition application through the LBPH algorithm method and as learning in the manufacture of face recognition applications for Android-based teaching attendance through the LBPH method.

While the benefits to achieve this research are to increase knowledge in making information systems in the form of applications using Face Recognition applications and adding knowledge in the manufacture of the teaching

* Corresponding author

This is an Creative Commons License This work is licensed under a Creative

Commons Attribution-NoDerivatives 4.0 International License. 


\section{Journal of Computer Networks, Architecture and High Performance Computing}

Volume 3, Number 2, April 2021

https://doi.org/10.47709/cnahpc.v3i2.981
Submitted : 15 June 2021

Accepted : 20 June 2021

Published : 19 July 2021

lecturer attendance information system with facial recognition with the LBPH algorithm by using Android devices.

\section{LITERATURE REVIEW}

In the development of biological identification systems science and technology such as fingers, faces, retina, sounds, and others are widely used (Zafaruddin \& Fadewar, 2018). One biological information that has been developed and has a high accuracy value is facing. Everyone's face has uniqueness (Muliawan et al., 2015).

Through an identification system for facial recognition, the face can be used to recognize someone in office administration activities such as attendance, data collection, and security systems (Marti \& Yota, 2016). Because it is considered to have its characteristics, the face is one of the identification tools that are difficult to engineer, with the condition of the room, light aspect, skin color, hairstyle, and accessories used (Wuryandari \& Afrianto, 2012).

The Local Binary Pattern Histogram (LBPH) algorithm is one of the most effective methods for facial recognition (Retno Choirunisa, 2021). According to several existing research sources, previously explained that the Local Binary Pattern Histogram method has calculations that are quite fast and produce efficient facial characteristics due to the simple algorithm (Yusvida Putri, 2019).

Eigenface is a method that uses faces or photos of faces as an input element, through a set of eigenvectors used to identify the human face. Based on the development carried out by Sirivich and Kirby in 1987, then used by Matthew Turk and Alex Pentland for the tool classifying faces. A Face recognition system is a computer application used to identify or verify someone automatically from a digital image or video as the source of input (Santoso \& Kusuma, 2018)(Arya et al., 2015).

Face recognition is one of the new biometric methods, various studies have been carried out in testing several facial recognition methods that aim to find the best method capable of achieving high accuracy values in recognizing faces (Efendi et al., 2017). Face recognition is one of the main aspects of computer technology that has a variety of applications including security systems, augmented reality, real-time identification, and more (Hermosilla et al., 2018).

Research has been conducted that used the face recognition system through the Eigenface method through an analysis of two forms of errors namely the False acceptance rate (FAR), namely an error in recognizing the identity of the registered input image or not registered and analysis of the false rejection rate (FRR), namely the error in rejecting the image Input that should be recognized changes to not recognizable. The study produced that the Eigenface method was able to achieve the best accuracy (the upper threshold) in facial recognition of $84.6 \%$ with FAR $($ False acceptance rate $)=16.2 \%$ and FRR $($ False rejection rate $)=20 \%$ (Fisika, 2012)

Furthermore, in this study, the author would discuss the application of human facial recognition using the LBPH algorithm. The aim is to seek the best accuracy and the average value of accuracy or the level of introduction that can be achieved using the Face Recognition application so that it is known how much the ability to apply the LBPH algorithm in recognizing the face image.

In the face recognition system, it takes a computer to process the digital signal from the identification of a face then match it with an existing database. This identification process requires a device, in this study the author uses Android devices.

\section{METHOD}

In this study, the authors conducted data through literature study studies from several journals reading sources, and articles on internet media which were later developed through an experimental method where the experiment media is by developing application/software through speed detection using OpenCV. The Local Binary Pattern Histogram (LBPH) method will be embedded in facial detecting software. 


\section{Journal of Computer Networks, Architecture and High Performance Computing}

Volume 3, Number 2, April 2021

https://doi.org/10.47709/cnahpc.v3i2.981
Submitted : 15 June 2021

Accepted : 20 June 2021

Published : 19 July 2021

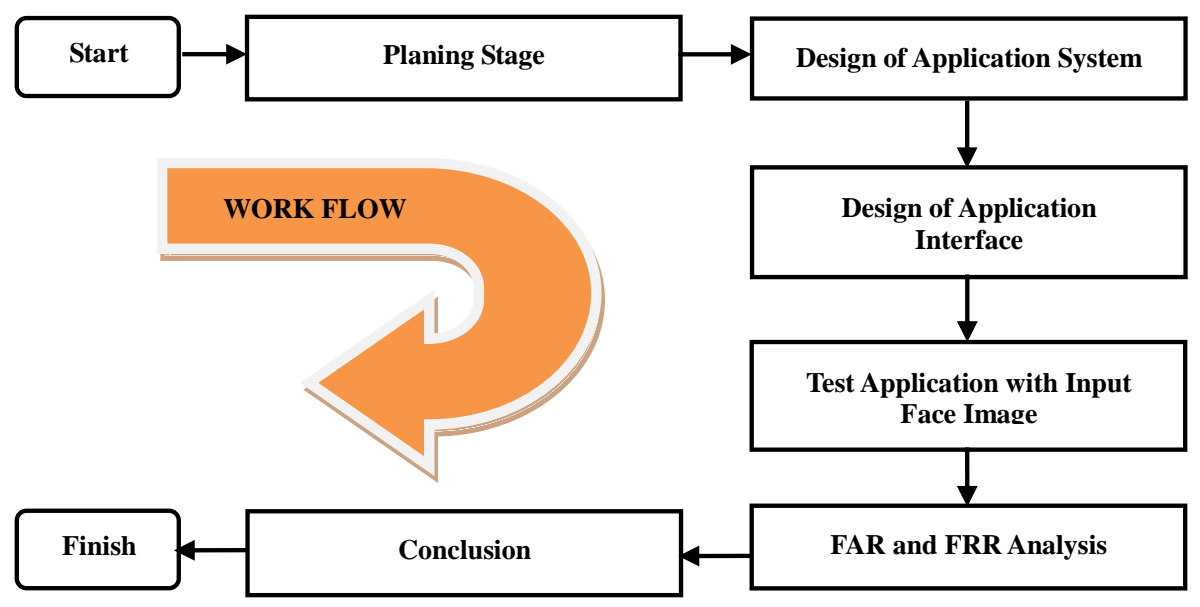

Fig. 1 Research Method Flow Process

Fig. 1 showed a process flow diagram, the research was carried out from the stage of planning, design, trial, FAR, and FRR analysis, to the stage of concluding the results of the study.

\section{RESULTS}

With the application of the LBPH method on the face recognition application, which is then analyzed by False acceptance rate (FAR) and False rejection rate (FRR), the results obtained that using the LBPH method can be achieved better accuracy than using the eigenface method. At the average number of test results as a whole LBPH can achieve better accuracy than using the eigenface method. Based on the results of the calculation of the FAR and FRR which is an error value in receiving registered image images, in the LBPH method, the ratio of its error is smaller than using the eigenface method.

\section{DISCUSSION}

In the system extract the introduction of the face image, one of the known extraction methods is the Local Binary Pattern (LBP) method this approach by Ojala et al in 1996 (Mujib et al., 2018).

LBP is a combination of the histogram menu with a classification of human faces, a new technique for developing the LBP method in increasing the performance identification of facial recognition. LPB is designed as a tool for recognizing texture (D. Retnoningrum, A.W. Widodo, 2019). For facial recognition application methods, it is recommended using LBPH which will be implemented on Android system operations with simple reasons in the calculation, on the other hand, this method has a small storage capacity so that it can be applied using Android and has more accuracy level Good compared to other methods (A. Fauzan, L. Vovamizanti, S.Si, 2018). The basic methodology for facial descriptions using LBPH is delivered as shown in Fig. 2 :

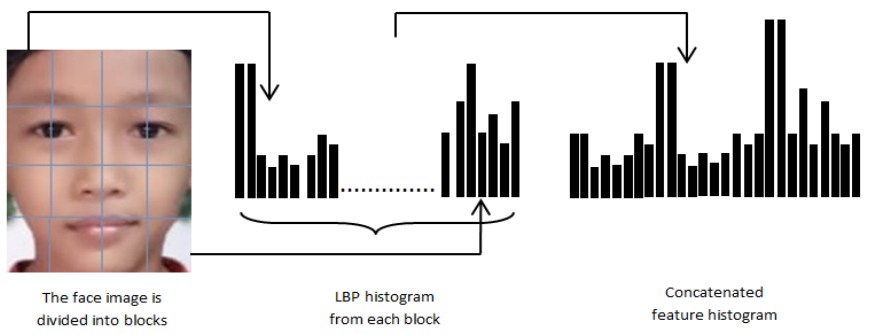

Fig. 2 Example of LBPH-based facial representation 


\section{Journal of Computer Networks, Architecture and High Performance Computing}

Submitted : 15 June 2021

Volume 3, Number 2, April 2021

https://doi.org/10.47709/cnahpc.v3i2.981

Fig. 2 describes the representation of the face using the LBPH method, namely facial images divided into local areas and LBP texture descriptors are extracted from each region independently, the descriptor is then coupled to a global face description.

\section{Testing parameters}

This study have a testing parameter to find the level of face recognition accuracy, which is by dividing between the number of samples that succeed with the number of trial samples, then multiplied by $100 \%$ (1). So if written in the equation are as follows:

$$
\text { Accuracy }=\frac{\text { Succesfull test }}{\text { Number of experiments }} \times 100 \%
$$

False acceptance rate (FAR) is an error in recognizing a registered face or yet (2). So to calculate the FAR equation is:

$$
F A R=\frac{\text { Many FAR }}{\text { Number of experiments }} \times 100 \%
$$

Then the false rejection rate (FRR) is a mistake in processing the image input. An image received that should be recognized changes to not recognizable (3). The formula used to calculate FRR is:

$$
F R R=\frac{\text { Many FRR }}{\text { Number of experiments }} \times 100 \%
$$

\section{Testing conditions}

The provisions used in testing this study are carried out by inputting sample image images overlooking the camera with no expression in the room during the day without additional light lights as lighting.

\section{System test results}

In conducting testing, the average data is obtained by the calculation of the accuracy of introduction, FAR, and FRR as follows:

Table 1. Results of LBPH and Eigenface Testing

\begin{tabular}{ccccccc}
\hline \multirow{2}{*}{ Testing } & \multicolumn{3}{c}{ LBPH } & \multicolumn{3}{c}{ Eigenface } \\
\cline { 2 - 7 } & $\begin{array}{c}\text { Accuration } \\
(\boldsymbol{\%})\end{array}$ & $\begin{array}{c}\text { FAR } \\
(\boldsymbol{\%})\end{array}$ & $\begin{array}{c}\text { FRR } \\
(\mathbf{\%})\end{array}$ & $\begin{array}{c}\text { Accuration } \\
(\boldsymbol{\%})\end{array}$ & $\begin{array}{c}\text { FAR } \\
(\boldsymbol{\%})\end{array}$ & $\begin{array}{c}\text { FRR } \\
(\boldsymbol{\%})\end{array}$ \\
\hline 1 & 90,00 & 0 & 3,33 & 84,6 & 16,6 & 20 \\
2 & 96,67 & 0 & 1,11 & 78,2 & 24,7 & 17,5 \\
3 & 96,67 & 0 & 1,11 & 77,1 & 26,1 & 16,7 \\
4 & 93,33 & 0 & 2,22 & 76,4 & 27,5 & 15,8 \\
5 & 93,33 & 0 & 2,22 & 74,8 & 29,1 & 15,8 \\
6 & 100,00 & 0 & 2,22 & 71,8 & 33,2 & 13,6 \\
7 & 100,00 & 0 & 0 & 71,1 & 33,8 & 11,7 \\
\hline Average & $\mathbf{9 5 , 7 1}$ & $\mathbf{0}$ & $\mathbf{1 , 7 4}$ & $\mathbf{7 6 , 2 8}$ & $\mathbf{2 7 , 2 8}$ & $\mathbf{1 5 , 8 7}$ \\
\hline
\end{tabular}

Table 1 is the results of LBPH and Eigenface testing as many as 7 trial times in a room during the day without the help of light lighting. 


\section{Journal of Computer Networks, Architecture and High Performance Computing}

Volume 3, Number 2, April 2021

https://doi.org/10.47709/cnahpc.v3i2.981
Submitted : 15 June 2021

Accepted : 20 June 2021

Published : 19 July 2021

From the results, the test can be seen in the comparison diagram of LBPH and Eigenface in Fig. 3.

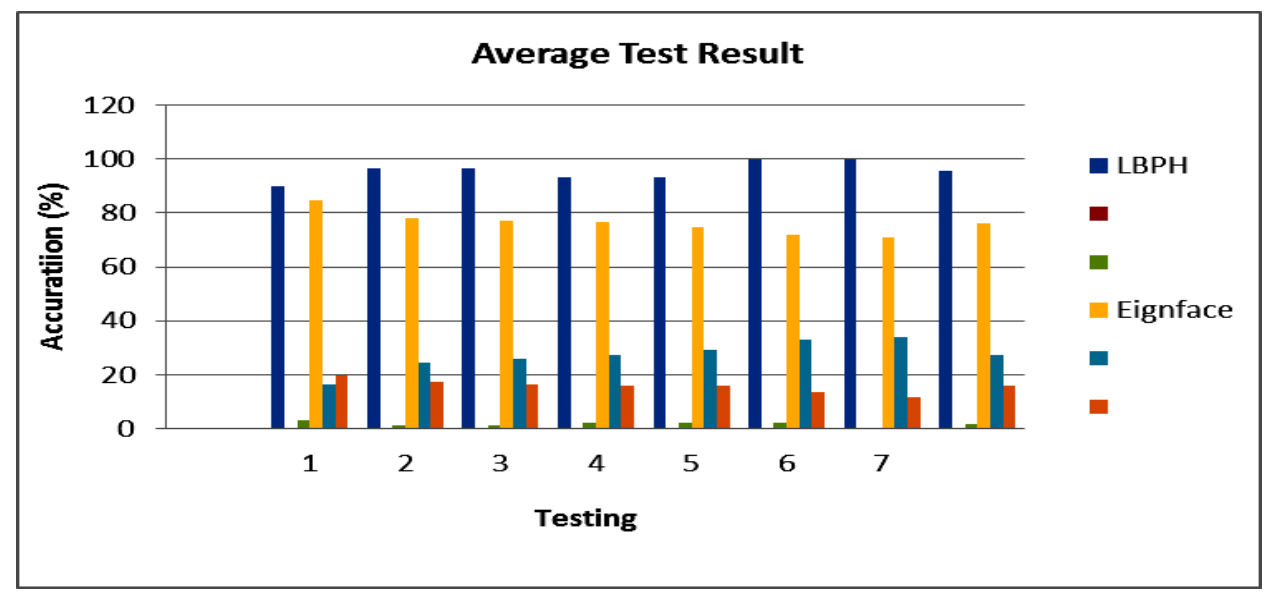

Fig. 3 The average comparison diagram of LBPH and Eigenface accuracy

In Fig. 3 is a form of display visualization of bar diagrams based on the test results data that has been carried out by the previous table. Of the several test results that have been done, LBPH is able to achieve its best accuracy in the upper threshold of $100 \%$ while the Eigenface reaches the best accuracy of $84.6 \%$. At the average number of test results as a whole LBPH was able to reach $95.71 \%$ accuracy while Eigenface was only $76.28 \%$. Based on the calculation of the FAR and FRR which is an error value of rejecting the input image and error in recognizing images, the LBPH method has a smaller accuracy value compared to the Eigenface, which is with the value of the FAR average result of $0 \%$ and the FRR value of $1.74 \%$ The level of mistakes ratio is smaller in LBPH compared to the FAR average value in the Eigenface method of $27.28 \%$ and FRR value of $15.87 \%$.

\section{The results of testing for face recognition attendance applications}

Here is the result of the image display of attendance application testing based on face recognition using the Face Recognition application:

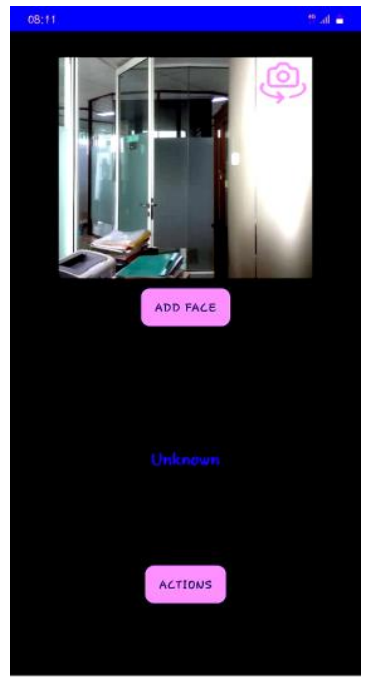

Fig 4. Face Recognition Application Ready

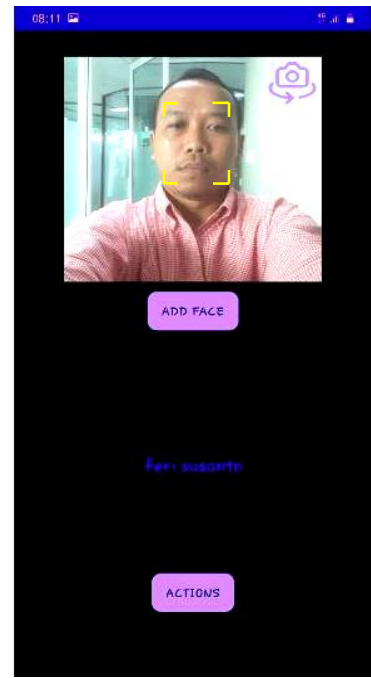

Fig 5. The Application Accepts The First Image

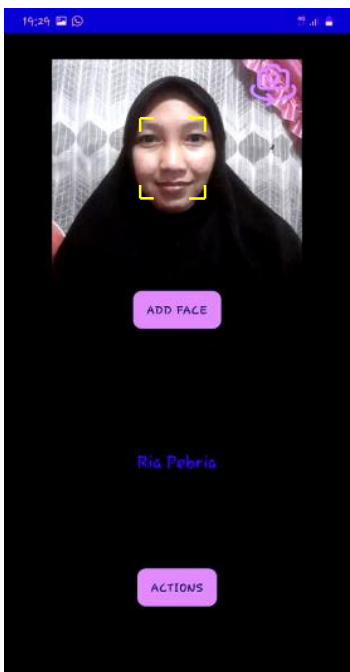

Fig 6. The Application Accept of The Second Image 


\section{Journal of Computer Networks, Architecture and High Performance Computing}

Submitted : 15 June 2021

Volume 3, Number 2, April 2021

https://doi.org/10.47709/cnahpc.v3i2.981

From Fig. 4 it can be explained that the image is a display when the Face Recognition application is in a ready condition, no image is input.

Then in Fig. 5 and 6 there are accepts images input with the registered, and the system can recognize the face of the input image according to the identity registered.

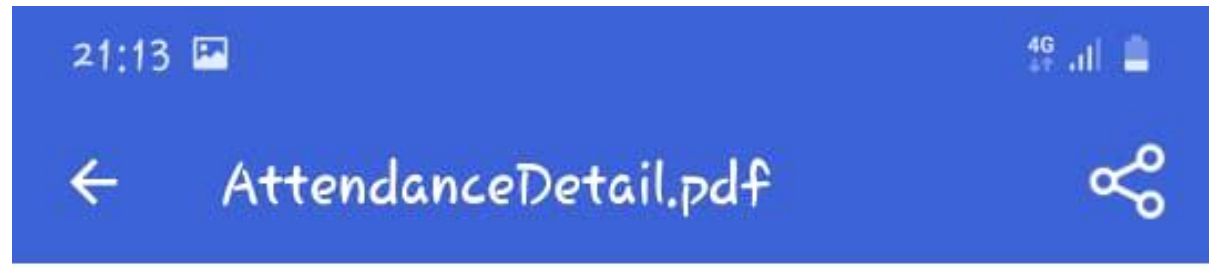

\begin{tabular}{|l|l|l|l|l|l|l|l|l|}
\hline Daily Attendance Report from 2021-05-22 to 2021-05-23 \\
\hline ID & Code & $\begin{array}{l}\text { Enroll } \\
\text { Image }\end{array}$ & Date & $\begin{array}{l}\text { In } \\
\text { Image }\end{array}$ & In Time & $\begin{array}{l}\text { Out } \\
\text { Image }\end{array}$ & $\begin{array}{l}\text { Out } \\
\text { Time }\end{array}$ & Hrs \\
\hline 2 & $\begin{array}{l}\text { Ria } \\
\text { Pebria }\end{array}$ & & $\begin{array}{l}2021- \\
05-22\end{array}$ & & $\begin{array}{l}19: 15: 3 \\
6\end{array}$ & & $\begin{array}{l}19: 15: 3 \\
6: 0\end{array}$ & 0 \\
\hline 1 & $\begin{array}{l}\text { feri } \\
\text { susanto }\end{array}$ & 7 & $\begin{array}{l}2021- \\
05-22\end{array}$ & 7 & $\begin{array}{l}19: 09: 0 \\
9\end{array}$ & 7 & $19: 09: 4$ & $0: 0$ \\
\hline
\end{tabular}

Fig. 7. Database Report Daily Attendance

Fig. 7 is a display of the results of the database recording in the Face Recognition application used as an example of the lecturer attendance application. There is a list of images, time and date when the lecturer has attended by using the Face Recognition application.

\section{CONCLUSION}

In this study the author can conclude the face recognition system with the LBPH method can be used the Face Recognition application with the condition of the room in the day of the day with the help of sunlight as lighting without additional light lamps with an average accuracy of face recognition greater than the Eigenface method, namely with LBPH produce The average value of accuracy was $95.71 \%$ while the Eigenface method was 76.28. While at the average value of the False Acceptance Rate (FAR) the LBPH method is also lower than the Eigenface method, which is the average value of the FAR LBPH method is produced 0\% while the Eigenface method is $27.28 \%$, meaning that the smaller the FAR value will be the greater The level of accuracy of his face recognition. The average rate of False Rejection (FRR) LBPH method is lower than the Eigenface method, namely the average value of FRR with the LBPH method of $1.74 \%$ and the Eigenface method of $15.87 \%$ means the smaller FRR, the greater The level of accuracy of his face recognition.

\section{REFERENCES}

A. Fauzan, L. Vovamizanti, S.Si, and Y. N. F. (2018). Implementation Identification of Face Recognition Using LBPH (Local Binary Pattern Histogram) Method For Attendance Presence Based Android. EProceedings of Engineering, 5(3), 5403-5413.

Arya, S., Pratap, N., \& Bhatia, K. (2015). Future of Face Recognition: A Review. Procedia Computer Science, 58, 578-585. https://doi.org/10.1016/j.procs.2015.08.076

D. Retnoningrum, A.W. Widodo, dan M. A. R. (2019). Ekstraksi Ciri Pada Telapak Tangan Dengan Metode Local Binary Pattern (LBP). 3(3), 2611-2618. 


\section{Journal of Computer Networks, Architecture and High Performance Computing}

Volume 3, Number 2, April 2021

https://doi.org/10.47709/cnahpc.v3i2.981
Submitted : 15 June 2021

Accepted : 20 June 2021

Published : 19 July 2021

Efendi, J., Zul, M. I., \& Yunanto, W. (2017). Real time face recognition using eigenface and viola-jones face detector. International Journal on Informatics Visualization, 1(1), 16-22. https://doi.org/10.30630/joiv.1.1.15

Fisika, B. (2012). Sistem Pengenalan Wajah Dengan Metode Eigenface Dan Jaringan Syaraf Tiruan (Jst). Berkala Fisika, 15(1), 15-20.

Gilang Aditya Rama, Fauziah, N. (2020). Perancangan Sistem Keamanan Brangkas Menggunakan Pengenalan Wajah Bderbasis Android. Media Informatika Budidarma, 4(3), 635-641.

Hermosilla, G., Rojas, M., Mendoza, J., Farías, G., Pizarro, F. T., Martín, C. S., \& Vera, E. (2018). Particle Swarm Optimization for the Fusion of Thermal and Visible Descriptors in Face Recognition Systems. IEEE Access, 6 , 42800-42811. https://doi.org/10.1109/ACCESS.2018.2850281

Marti, N. W., \& Yota, K. A. E. (2016). Prototipe Sistem Absensi Berbasis Face Recognition Dengan Metode Eigenface. Seminar Nasional Vokasi Dan Teknologi, 451-456.

Mujib, K., Hidayatno, A., \& Prakoso, T. (2018). Pengenalan Wajah Menggunakan Local Binary Pattern (Lbp) Dan Support Vector Machine (Svm). Transient, 7(1), 123. https://doi.org/10.14710/transient.7.1.123-130

Muliawan, M. R., Irawan, B., \& Brianorman, Y. (2015). Implementasi Pengenalan Wajah Dengan Metode Eigenface Pada Sistem Absensi. Jurnal Coding, Sistem Komputer Untan, 03(1), 41-50. http://jurnal.untan.ac.id/index.php/jcskommipa/article/viewFile/9727/9500

Retno Choirunisa. (2021). Identifikasi Pola Wajah Menggunakan Metode Local Binary Pattern Histogram.

Rosita, E., \& Wibowo, R. A. (2021). The Effect of the Interdependence of the Corporate Governance Mechanism on Firm Value in Manufacturing Companies Listed on the Indonesia Stock Exchange. Accounting and Finance ..., Idx, 1-19. https://profesionalmudacendekia.com/index.php/afs/article/view/65

Santoso, K., \& Kusuma, G. P. (2018). Face Recognition Using Modified OpenFace. Procedia Computer Science, 135, 510-517. https://doi.org/10.1016/j.procs.2018.08.203

Satria Putra, Iskandar Fitri, S. N. (2021). Absensi Pengenalan Wajah Menggunakan Menggunakan Algoritma Eigenface Berbasis Web. Journal of Applied Informatics and Computing (JAIC), 5(1), 21-27.

Wuryandari, M. D., \& Afrianto, I. (2012). Perbandingan Metode Jaringan Syaraf Tiruan Backpropagation Dan Learning Vector Quantization Pada Pengenalan Wajah. Komputa, 1(1), 45-51.

Yusvida Putri. (2019). Pengenalan ekspresi wajah menggunakan metode local binary pattern histogram dan jaringan syaraf tiruan". Komputer, . J. S., Komputer, F. I., \& \& Sriwijaya.

Zafaruddin, G. M., \& Fadewar, H. S. (2018). Face recognition using eigenfaces. Advances in Intelligent Systems and Computing, 810(5), 855-864. https://doi.org/10.1007/978-981-13-1513-8_87 